\title{
Erratum to: Bankart repair versus Bankart repair plus remplissage: an in vitro biomechanical comparative study
}

Jean Grimberg • Amadou Diop - Rony Bou Ghosn •

Dimitri Lanari · Adrien Canonne • Nathalie Maurel

Published online: 12 June 2014

(c) Springer-Verlag Berlin Heidelberg 2014

Erratum to: Knee Surg Sports Traumatol Arthrosc

DOI 10.1007/s00167-014-3052-z

Unfortunately, the author Rony Bou Ghosn's name was published incorrectly in the original publication. The correct first name is Rony and the family name is Bou Ghosn.

The online version of the original article can be found under doi:10.1007/s00167-014-3052-z.

J. Grimberg $(\bowtie) \cdot$ R. Bou Ghosn

Institut de Recherche en Chirurgie Orthopédique et Sportive (IRCOS), 6 Avenue Alphonse XIII, 75016 Paris, France

e-mail: j.grimberg@lircos.org

A. Diop - D. Lanari - A. Canonne $\cdot$ N. Maurel

Equipe Biomécanique et Remodelage Osseux (EPBRO),

Arts et Métiers ParisTech, 151 Boulevard de l'Hôpital,

75013 Paris, France 